Niniejsza publikacja jest dostęna na licencji Creative Commons. Uznanie autorstwa-Użycie niekomercyjne-Bez utworów zależnych 3.0 Polska. Pewne prawa zastrzė̇one na rzecz autora. Zezwala się na wykorzystanie publikacji zgodnie z licencja - pod warunkiem zachowania niniejszej informacji licencyjnej oraz wskazania autora jako właściciela praw do tekstu. Treść licencji jest dostępna na stronie: http://creativecommons.org/licenses/by-nc-nd/3.0/pl/

Lingwistyka Stosowana 23: 3/2017, 197-211

\author{
Emil Daniel LESNER
}

Uniwersytet Szczeciński

\title{
O tworzeniu i technikach przekładu tzw. ,easter eggów“ na wy- branych przykładach z trylogii gier komputerowych „Wiedźmin“ i jej thumaczenia na język niemiecki
}

\begin{abstract}
:
The different ways of creating and translating easter eggs on example of computer games trilogy "The Witcher" and its German renditions.

In his article the author discusses the different ways of creating and translating of so-called easter eggs according to i.a.. polysystem theory of Itamar Even-Zohar. The corpus of analysis are the quest names of popular computer games trilogy "The Witcher" with its whole Digital-Loop-Carrier-Package and its German rendition.
\end{abstract}

\section{Wstęp}

W niniejszym artykule zostanie omówiony problem tworzenia i przekładu tzw. „easter eggów". Jako że wspomniany termin stosowany jest głównie w socjolekcie użytkowników komputera, podejmiemy próbę językoznawczego opisu ww. pojęcia. W części praktycznej dokonamy jakościowej analizy technik tłumaczenia, które można zastosować w procesie przekładu omawianego tu zjawiska językowego. Korpus badawczy stanowią wybrane przykłady z opartej na twórczości A. Sapkowskiego trylogii gier komputerowych „Wiedźmin” wraz ze wszystkimi opublikowanymi rozszerzeniami fabularnymi i ich thumaczenia na język niemiecki.

\section{Easter eggi jako rodzaj aluzji}

Źródła internetowe definiują pojęcie easter egg jako „różnego rodzaju nawiązania do rzeczywistości (również wirtualnej) zamieszczane przez twórców w swoich produkcjach. Mają najczęściej akcent humorystyczny” (zob. Easter Egg 2016).

Zastosowanie w przytoczonej powyżej definicji rzeczownika nawiazanie oraz przymiotnika humorystyczny klasyfikuje pojęcie easter egg jako rodzaj aluzji o sprecyzowanej funkcji pragmatycznej, występujący przede wszystkim w wytworach kultury popularnej. Słownik aluzji opisuje ją w następujący sposób: 
Aluzja może być definiowana jako nawiązanie do nazwy osoby obecnej w życiu realnym, wydarzenia historycznego lub postaci literackiej, które nie jest wyrażone w sposób bezpośredni (jak np. w zdaniu „Herkules był starożytnym greckim herosem”), lecz zawiera w sobie znaczenie dodatkowe, będące wyrazem pewnych cech charakterystycznych, względnie jakościowych, danego denotatu. Aluzją byłoby więc określenie skąpca jako Scrooge, pięknej kobiety jako Wenus, a także nazwanie siłacza Herkulesem ${ }^{1}$ [AL: VII, thum. E.L.].

Aluzje mogą tym samym spełniać w danym utworze różnorodne funkcje. N.V. Cherkas (2004) wymienia m.in. ich estetyczną oraz symboliczną rolę, a P. Lennon (2001: 21) podkreśla, że ich podstawową funkcją jest rozbudzenie ciekawości odbiorcy i skupienie jego uwagi na danym produkcie ${ }^{2}$. W przypadku opisywanych easter eggów dominuje funkcja ludyczna (ich nadrzędną rolą jest więc rozbawienie odbiorcy, a także satysfakcja płynąca z odszyfrowania wytworzonej sieci nawiązań międzykulturowych).

Opisywane $\mathrm{w}$ ten sposób easter eggi byłyby więc wyrazem intertekstualności (definiowanej w rozumieniu W. Heinemanna jako „potwierdzona relacja między dwoma lub więcej tekstami”’3) o funkcji ludycznej. Wspomniana relacja może się przejawiać zarówno poprzez dokładne odwołania do innych tekstów (easter eggi mogą tym samym przyjmować postać tzw. intertekstualności właściwej), a także może zależeć od indywidualnej wiedzy i możliwości interpretacyjnych danego odbiorcy, przyjmując formę tzw. intertekstualności fakultatywnej. ${ }^{4}$

\section{Easter eggi a proces tworzenia}

Podobnie jak w przypadku aluzji, możliwości tworzenia easter eggów jawią się jako nieograniczone ${ }^{5}$. Wynika to przede wszystkim z trzech czynników, tzn. postmodernistycznych cech kulturowych, postępującego rozwoju technologicznego na świecie oraz z relacji polisystemowych.

Pierwszy z wymienionych charakteryzuje motywację autorów. Postmodernizm jako dominująca obecnie epoka kulturowa wykształcił w obrębie szeroko pojętej

\footnotetext{
${ }^{1}$ Zob. tekst oryginalny: „An allusion may be defined as the mention of the name of a real person, historical event, or literary character which is not simply a straightforward reference (as in 'Hecules was an ancient Greek hero') but which conjures up some extra meaning, embodying some quality or characteristic for which the word has come to stand. So we can describe a miser as a Scrooge, a strong man as a Hercules, a beautiful woman as a Venus." [AL: VII]

${ }^{2}$ Leksem produkt został tu użyty celowo dla podkreślenia obecności aluzji w różnych wytworach kultury (wysokiej oraz masowej), tj. literaturze, sztuce wizualnej i multimediach.

${ }^{3}$ Zob. tekst oryginalny: „eine ausweisbare Relation zwischen zwei oder mehreren Texten” (W. Heinemann 1997: 24, thum.: E.L.)

${ }^{4}$ Terminy intertekstualność właściwa oraz intertekstualność fakultatywna zostały w wyczerpujący sposób wyjaśnione w pracy D. Urbanek (2004: 137).

${ }^{5} \mathrm{~W}$ czasach powszechnego i szybkiego dostępu do informacji oraz prężnego rozwoju kultury audio-wizualnej i tekstowej hipoteza o nieograniczonych możliwościach tworzenia aluzji jest coraz bardziej popularna (zob. G. Heidemann 2017).
} 
twórczości artystycznej pewne charakterystyczne cechy, do których można zaliczyć m.in. niechęć wobec autorytetów i tradycji, antyrealizm, antyobiektywizm oraz zamiłowanie do cytatów oraz plagiatu (zob. M. Świerkocki 1997: 66-67). M. Dąbrowski (2000: 27) wymienia w swojej monografii także dystans, ironię, eseizację, brak podmiotowości, nieciągłość, zagubienie identyczności postaci i grę konwencjami literackimi. Epoka postmodernizmu czerpie natchnienie z wcześniej stworzonych dzieł parodiując, przetwarzając i naśladując minione epoki; w dużej mierze korzysta z gotowych wzorców, powtarzając i przepisując ich dotychczasowy dorobek. Postmodernistyczna twórczość jest aktywnością wiecznie odnoszącą się do siebie samej i cytującą samą siebie, oznaczającą mnogość (zob. M. Świerkocki 1997: 72-73 oraz A. Kiklewicz 2006: 74).

Postępujący rozwój technologiczny w skali globalnej wpływa natomiast na możliwości odbioru produktów kultury. Niezwykle istotną rolę w tym zakresie pełni internet z jednej strony łącząc wynalazek J. Gutenberga z medium audio-wizualnym, z drugiej zaś otwierając nowe perspektywy dla publikacji własnej twórczości oraz dla dostępu do informacji i wiedzy (więcej na ten temat: zob. E. Hendryk 2001: 912). Wspomniany wzrost możliwości dostępu do informacji i wiedzy wpływa więc na indywidualne zdolności interpretacyjne odbiorców i ich możliwości odszyfrowywania ukrytych aluzji oraz easter eggów. Obecnie odbiorca danego utworu może przy pomocy jednego kliknięcia myszką sprawdzić na danym portalu internetowym, czy dana jednostka leksykalna funkcjonuje w obrębie danego polisystemu, czy też jest kulturowo neutralna.

Trzecim czynnikiem determinującym możliwości tworzenia easter eggów jest polisystem jako zjawisko o dynamicznym charakterze, które zostało szczegółowego opisane i wprowadzone do dyskursu naukowego w roku 1990 przez izraelskiego uczonego I. Evena-Zohara. Przedstawił on je jako

Sieć relacji [...] zachodzących między pewną ilością aktywności określanych jako literackie, a także wspomniane aktywności. ${ }^{6}$ (I. Even-Zohar 1990: 28, thum.: E.L.).

Należy podkreślić, że zjawisko opisane przez I. Evena-Zohara odnosiło się tylko i wyłącznie do aktywności o charakterze literackim, co w przypadku obecnego rozwoju kultury popularnej i opisywanego powyżej rozwoju technologicznego nakłania do rozszerzenia ww. pojęcia również na inne dziedziny kultury. Argumentem przemawiającym za rozszerzeniem wprowadzonego w roku 1990 pojęcia polisystemu byłby fakt, że polisystem jawi się w teorii I. Evena-Zohara jako konsekwencja intertekstualności, a w myśl nowszych teorii intertekstualność może być rozumiana nie tylko jako relacja między dwoma lub więcej tekstami, ale także jako sugerowana m.in. przez R. Nycza relacja tekst vs. tekst kultury, która określa odniesienia do innych zjawisk kulturowych, tj. utworów muzycznych lub obrazów ${ }^{7}$ (zob. R. Nycz

${ }^{6}$ Zob. tekst oryginalny: „The network of relations [...] hypothetisized to obtain between a number of activities called "literary", and consequently these activities themselves observed via that network."

${ }^{7}$ Postrzeganie obrazu w kategoriach tekstowych wiąże się bezpośrednio z ujęciem sztuki wizualnej jako utworu o ,nieskończonej ilości układów strukturalnych i systemów teksto- 
2000). W odniesieniu do opisywanej zależności między tekstami a tekstami kulturowymi polisystem obejmowałby oprócz aktywności literackich, również aktywności muzyczne (teksty piosenek), kinematograficzne (zbiór cytatów filmowych oraz tytułów filmów i ich tłumaczeń), multimedialne (tytuły i cytaty z gier komputerowych $\mathrm{i}$ in.), a nawet społeczne (wszelkiego rodzaju szeroko komentowane w mediach cytaty aktywistów społecznych). Podobnie jak w przypadku polisystemu literackiego niezwykle istotną rolę dla rozwoju tak szeroko pojmowanych polisystemów pełnią thumaczenia, mające decydujący wpływ na kształtowanie się tzw. interrelacji, a więc związków rodzimych produktów kulturowych $\mathrm{z}$ wpływami zagranicznymi, które odbiorcy są $\mathrm{w}$ stanie poznać jedynie poprzez przekłady $\mathrm{z}$ innych języków (zob. I. Even-Zohar 1990: 23). Aktywności translatorskie mają więc znaczący wpływ na dynamiczny charakter danego polisystemu, będąc jednocześnie źródłem nowych inspiracji dla tworzenia aluzji i easter eggów.

Na podstawie ściśle określonego rodzaju aktywności, do którego nawiązują, opisywane przez nas easter eggi można podzielić na trzy grupy, $\mathrm{tj}$. na tzw. easter eggi wizualne, easter eggi akustyczne oraz easter eggi tekstowe.

Easter eggi wizualne polegają na odwołaniu się do pewnego obrazu, pewnej ściśle określonej sceny, która jest znana odbiorcom z innych produktów kultury.

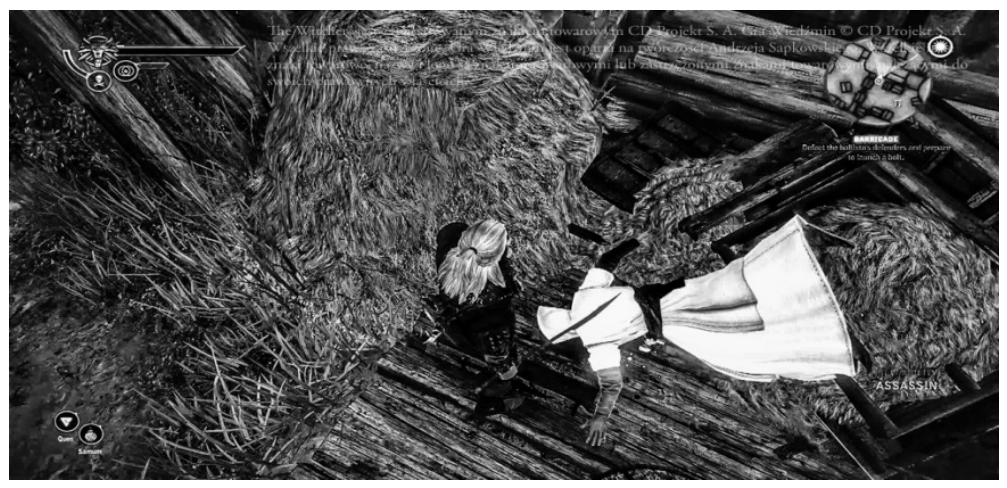

Ryc. 1. Wiedźmin 2: Zabójcy Królów ${ }^{8}$.

Powyższe zdjęcie ukazuje nawiązanie do popularnego wśród młodzieży cyklu gier komputerowych i filmów fabularnych „Assassin's Creed”. Wspomniana aluzja objawia się tu poprzez obecność zakapturzonej postaci w białym płaszczu na wozie z sianem. Przekazywanie easter eggu następuje poprzez kanał optyczny, a źródłem

wych”, na których opiera się „długotrwała nośność estetyczna malarstwa” (więcej na ten temat: zob. L. Kalinowski 1981: 118).

${ }^{8}$ The Witcher® jest zarejestrowanym znakiem towarowym CD-Projekt S.A. Gra Wiedźmin (C) CD Projekt S.A. Wszelkie prawa zastrzeżone. Gra Wiedźmin jest oparta na twórczości Andrzeja Sapkowskiego. Wszelkie inne znaki towarowe, nazwy i logo są znakami towarowymi lub zastrzeżonymi znakami towarowymi, należącymi do swoich prawowitych właścicieli. 
odniesienia mogą być różnorodne produkty kultury wizualnej, tj. obrazy, produkty multimedialne lub kinematografia.

Grupa akustycznych easter eggów obejmuje nawiązania do popularnych, obecnych w kulturze wysokiej oraz masowej utworów muzycznych.

Na Wojtusia....

$\mathrm{Na}$ Wojtusia z

popielnika iskie- $\quad-/{ }^{\prime}--/{ }^{\prime}--/$ ' - -

reczka mruga,

Chodź opowiem ci

bajeczkę, bajka

będzie długa...
Słońce zaszło...

\begin{tabular}{|c|c|c|}
\hline Słońce & zaszło, & ${ }^{\prime}--I^{\prime}--1{ }^{\prime}--1$ \\
\hline słowik & umilkł, & ${ }^{\prime}--1{ }^{\prime}--1{ }^{\prime}--1$ \\
\hline światło & już się & '- - \\
\hline
\end{tabular}

Księżyc wpełza

zza okiennic, ‘- - / '- - / '- - /

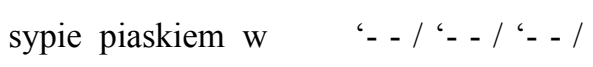

oczy

Ryc. 2. Wiedźmin 3: Dziki Gon.

W przytoczonym powyżej przykładzie z gry „Wiedźmin 3: Dziki Gon” tekst zamieszczony po prawej stronie wykorzystuje linię melodyczną popularnej kołysanki „Na Wojtusia z popielnika” (J. Porazińska 1925) przy całkowicie zmodyfikowanej warstwie lirycznej utworu. Przekazywanie aluzji następuje poprzez kanał akustyczny.

Easter eggi tekstowe stanowią odniesienia do konkretnych jednostek leksykalnych zawartych w ściśle określonych tekstach kultury. Wśród nich można wyróżnić easter eggi powstałe $\mathrm{w}$ wyniku zapożyczeń, przekładu oraz przeróbki. Pierwsza $\mathrm{z}$ wymienionych grup obejmuje jednostki leksykalne funkcjonujące w danym utworze na prawach bezpośredniego cytatu. Jako przykłady można tu podać wykorzystanie w trylogii gier komputerowych ,Wiedźmin” innych, znanych polskiemu odbiorcy tytułów, tj. Dziady, Ostatnie życzenie lub Nasza szkapa. Easter eggi powstałe w wyniku przekładu odnoszą się do wykorzystania w danym utworze tytułów pochodzących z innych dzieł, powstałych w obrębie obcych polisystemów. Przykładem tego typu aluzji w omawianych przez nas grach komputerowych byłoby użycie polskich tłumaczeń tytułów amerykańskich filmów, tj. Wykidajło, czy Teoria spisku. Zgodnie z definicją zaproponowaną przez M. Schreibera przeróbką (niem. Bearbeitung) nazywamy, ,intramedialną transformację tekstu wyjściowego mającą na celu zmianę jego ściśle określonych cech"9 (M. Schreiber 1993: 105, tłum.: E.L.). W przypadku omawianych easter eggów zmianie podlegają niektóre cechy semantyczne danej

${ }^{9}$ Zob. tekst oryginalny: „Eine Bearbeitung ist eine medienunabhängige Texttransformation, bei der mindestens ein komplexes, individuelles Textmerkmal erhalten bleibt und die ansonsten auf Varianzanforderungen beruht". 
jednostki tłumaczeniowej, inne zaś pozostają bez zmian, aby umożliwić odbiorcy adekwatną identyfikację aluzji. Przykładem easter eggu tekstowego, który powstał w wyniku przeróbki byłaby więc fraza nominalna Gangi Novigradu, gdzie toponim Nowy Jork został zastąpiony występującym w prozie A. Sapkowskiego toponimem Novigrad. Powstała w ten sposób jednostka leksykalna stanowi aluzję do popularnego filmu, znanego polskiemu odbiorcy pod tytułem Gangi Nowego Jorku (ang. Gangs of New York, zob. M. Scorsese 2002). Przekazywanie tego typu aluzji następuje poprzez kanał werbalny.

\section{Easter eggi a proces przekładu}

Ze względu na odniesienie do aktywności literackich, kinematograficznych, muzycznych, multimedialnych oraz społecznych opisywane easter eggi, podobnie jak wszelkie typy aluzji, powinny być traktowane jako elementy kulturowe. Ich przekładalność zależy od obecności w języku docelowym stosownych punktów odniesienia, do których tłumacz może odwołać się w procesie przekładu. E. Nida wspomina $\mathrm{w}$ tym kontekście o braku pewnych kategorii uniwersalnych $\mathrm{w}$ języku docelowym (zob. E. Nida 1969: 483). H. Lebiedziński omawiając przekładalność elementów kulturowych wymienia sytuacje, w których (1) odbiorcy tekstu docelowego nie znają obiektu denotowanego przez jednostkę leksykalną w języku wyjściowym, (2) dany denotat jest niewyrażalny w języku docelowym, (3) istnieją różnice w jego interpretacji wśród odbiorców w kulturze języka wyjściowego i docelowego lub (4) dochodzi do pewnych różnic kategorialnych między osobami z różnych kultur (zob. H. Lebiedziński 1989: 223-224). B. Schultze podkreśla natomiast, że język niemiecki nie posiada obecnych w polskiej literaturze atrybutów intelektualisty (tj. książka, okulary oraz gazeta), co stanowi problem w przypadku przekładu dramatu „Kartoteka" Tadeusza Różewicza (zob. B. Schultze 1992: 191). W tym samym kontekście P. Sulikowski wspomina o tzw. nawiazaniach intersemiotycznych (niem. intersemiotische Anspielungen), czyli o odniesieniach do fikcyjnych lub realnych osób, miejsc, dzieł artystycznych oraz pozostałych konstruktów zawartych w innych systemach semiotycznych (zob. P. Sulikowski 2013 oraz 2016: 38-39), podkreślając jednocześnie ich zmienność i dynamiczny charakter (por. m.in. odmienne skojarzenia z toponimem Guantanamo, który od roku 2002 kojarzy się przede wszystkim z niehumanitarnym traktowaniem jeńców wojennych, więcej na ten temat: zob. P. Sulikowski 2016: 40). Trudności wynikające z przekładu easter eggów tekstowych, które ze względu na swą budowę są dla thumaczy najbardziej istotne, wynikają więc z przyczyn typowo lingwistycznych (obecność w kulturze języka docelowego jednostki leksykalnej będącej źródłem aluzji lub jej brak) oraz z przyczyn antropocentrycznych (ze ściśle określonej wiedzy kulturowo-socjologicznej danego odbiorcy przekładu). Trudności lingwistyczne można przeważnie wyeliminować przy zastosowaniu adekwatnych technik przekładowych, tj. zapożyczenia (zob. R. Stolze 2005: 70) i autokomentarza (zob. J. Święch 1984: 46, 51). Znacznie bardziej problematyczna jest jednak sytuacja, w której odbiorcy translatu brakuje stosownej wiedzy kulturowej, bowiem to ona uzależnia potencjalny sukces thumaczenia od odbiorcy tekstu docelowego. 
Kolejnym istotnym aspektem w przypadku przekładu easter eggów jest niewielka rola wierności semantycznej (a więc tłumaczenia dosłownego) wobec tzw. funkcjonalnej adekwatności danej jednostki tłumaczeniowej względem jej ekwiwalentu. Funkcjonalna adekwatność przekładu względem tekstu wyjściowego jest gwarantowana poprzez zastosowanie w procesie przekładu tzw. funkcjonalnego ekwiwalentu lub poprzez znalezienie tzw. dominanty semantycznej. Termin ekwiwalent funkcjonalny używany jest według K. Lipińskiego dla określenia technik polegających na wprowadzeniu do tłumaczenia elementów kulturowych, które są odbiorcy tekstu docelowego bardziej znane i pełnią jednocześnie zbliżoną rolę do użytych w tekście wyjściowym (zob. K. Lipiński 2004: 23). Pojęcie dominanty semantycznej zostało wprowadzone przez S. Barańczaka dla nazwania tych cech tekstu wyjściowego, które nie powinny zostać znacznie zmodyfikowane w tekście docelowym (zob. S. Barańczak 2004: 20).

\section{Praktyczna analiza przykładów}

Opisywane w niniejszym artykule przykłady i ich niemieckie ekwiwalenty zostały podzielone na trzy grupy, tj. thumaczenie easter eggów utworzonych w wyniku procesu zapożyczenia, przekładu oraz przeróbki. Ze względów ekonomicznych w każdej grupie zostaną poddane dyskusji jedynie dwa przykłady. W odniesieniu do mocno wykształconych cech intertekstualnych opisywanych tu zjawisk oraz faktu, iż nadrzędną funkcją definiowanych powyżej easter eggów jest tworzenie w świadomości odbiorców skojarzeń z konkretnymi produktami kultury wysokiej lub/i masowej, wszystkie przytoczone przez nas przykłady zostaną opisane na dwóch poziomach analizy. Poziom referencyjny [REF] definiujemy za A. Kikleczem jako „opis odniesienia wyrażeń językowych do świata i in.” (2006: 24). Może być on porównany do ekwiwalencji denotatywnej w rozumieniu W. Kollera (zob. W. Koller 1992: 216). Na poziomie pragmatycznym [Prag] zostanie sprawdzone to, w jaki sposób jednostka tłumaczeniowa może oddziaływać na czytelnika tekstu wyjściowego, a jej ekwiwalent na odbiorcę translatu (por. pojęcie ekwiwalencji pragmatycznej u W. Kollera - zob. W. Koller 1992: 216). Poziom ten obejmuje kwestie stylistyczno-językowe, a także ewokowane u odbiorców tekstu wyjściowego i docelowego skojarzenia. Na potrzeby opisu przytoczonych przykładów posługiwać się będziemy monolingwalnymi słownikami języka niemieckiego oraz polskiego ([DUD] i [SZYM], odpowiednio). Wszystkie easter eggi zawarte w niniejszej pracy zostały zaczerpnięte $\mathrm{z}$ tytułów zadań stawianych użytkownikom gier komputerowych „Wiedźmin”, „Wiedźmin 2: Zabójcy królów” oraz „Wiedźmin 3: Dziki Gon” wraz ze wszystkimi opublikowanymi rozszerzeniami fabularnymi.

\subsection{Tłumaczenie easter eggów powstałych w wyniku zapożyczeń}

pol. Dziady - niem. Ahnenfest

Polska jednostka tłumaczeniowa odnosi się na poziomie [REF] do uroczystości obchodzonej między pospólstwem w powiatach Litwy, Prus i Kurlandii na pamiątkę 
dawnych przodków. Powyższy rzeczownik nawiązuje również do tytułu cyklu jednego z najważniejszych dramatów romantycznych Adama Mickiewicza, powstałych w latach 1823-1832 (zob. A. Mickiewicz 1832/2009: 8). Wspomniany utwór polskiego poety został przetłumaczony na język niemiecki przez wielu różnych tłumaczy, m.in. przez H. Lahra (1955, 1972), S. Lipinera (1955), H. Buddensiega (1957), G. Lebera-Hagenau'a (1968) oraz W. Schamschulę (1988, 1991). Do niemieckiego polisystemu przeniknęly dwa odmienne thumaczenia tytułu ww. dzieła, tj. „Die Ahnenfeier” (użyte dwa razy) oraz „Die Totenfeier” (użyte pięć razy) ${ }^{10}$. Thumacz gry komputerowej zdecydował się na rozwiązanie kreatywne i wprowadził do translatu rzeczownik złożony Ahnenfest, w którego skład wchodzą dwa rzeczowniki proste. Niemiecki leksem Ahnen [DUD] wyjaśnia jako „pot. przodek; przest. dziadek" Jednostka leksykalna Fest opisana jest tam jako „większe wydarzenie społeczne”"2, a także jako ,jeden lub dwa następujące po sobie dni świąteczne" ${ }^{13}$. Zaproponowany przez thumacza ekwiwalent odzwierciedla wprawdzie na poziomie [REF] istotę wzmiankowanej uroczystości, lecz nie odnosi się do istniejących w Niemczech tytułów thumaczeń dramatu A. Mickiewicza. Tłumacz dokonał więc neutralizacji na poziomie [Prag] przekładu zachowując przy tym wierność na poziomie [REF]. W celu uzyskania większej wierności pragmatycznej należałoby wprowadzić do niemieckiej wersji gry jedno z zaproponowanych wcześniej tłumaczeń tytułu polskiego dramatu (np. częściej występujący leksem Totenfeier).

\section{pol. Nasza szkapa - niem. Eine durchgegangene Stute}

Polska jednostka thumaczeniowa odnosi się do tytułu pozytywistycznej noweli M. Konopnickiej, postulującej takie wartości jak utylitaryzm oraz praca u podstaw, co wyraża m.in. zawarty w tytule zaimek dzierżawczy nasz (zob. [SZYM]: „oznacza, że to, co jest wyrażone przez rzeczownik, do którego się odnosi, jest w posiadaniu, w użytkowaniu itp. zespołu osób, z których jedną jest mówiący, lub jest częścią składową organizmu osoby mówiącej i innych osób"). Rzeczownik szkapa [SZYM] opisuje jako ,żartobliwie lub z politowaniem o koniu, zwłaszcza lichym, zabiedzonym”. I. Kuhnke (zob. I. Kuhnke 1995) podaje, że do niemieckiego polisystemu przeniknęły dwa tłumaczenia omawianego utworu. Autorem jednego z nich („Unser Pferdchen”, 1917) jest St. Strizek, drugiego zaś K. Harrer („Unser Gaul”, 1957). I tym razem thumacz proponuje rozwiązanie kreatywne w postaci frazy nominalnej eine durchgegangene Stute. Rzeczownik Stute wyjaśniony jest w [DUD] jako „samica konia"14, a przymiotnik durchgegangen wspomniany słownik opisuje w następujący sposób: „być postrzeganym jako młodszy, nowszy, lepszy niż w rzeczywi-

\footnotetext{
${ }^{10}$ Dane przytoczone za I. Kuhnke (zob. I. Kuhnke 1995).

11 [DUD]: ,(geh.) Vorfahr; (veraltet, noch landsch.) Großvater”, thum.: E.L.

12 [DUD]: ,[größere] gesellschaftliche Veranstaltung [in glanzvollem Rahmen]“, thum.: E.L.

13 [DUD]: ,ein einzelner od. zwei aufeinanderfolgende hohe kirchliche Feiertage“, thum.:

E.L.

${ }^{14}$ [DUD]: ,weibliches Pferd“, tłum.: E.L.
} 
stości"15. Na poziomie [REF] propozycja tłumacza uzupełnia przekład o dodatkowe informacje na temat sposobu postrzegania ww. szkapy przez społeczeństwo. Z pragmatycznego punktu widzenia nie jest to jednak propozycja udana, ponieważ nie ewokuje żadnych skojarzeń $\mathrm{z}$ istniejącymi w niemieckim polisystemie tłumaczeniami noweli M. Konopnickiej oraz stanowi zaprzeczenie założeń pozytywistycznych, tj. m.in. utylitaryzmu (przymiotnik durchgegangen sugeruje bowiem brak użyteczności tytułowego zwierzęcia w skali społecznej). W celu uzyskania większej wierności pragmatycznej należałoby wprowadzić do niemieckiej wersji gry jedno z zaproponowanych wcześniej tłumaczeń tytułu polskiej noweli.

\subsection{Tłumaczenie easter eggów powstałych w wyniku przekładu}

pol. Wykidajto - niem. Jetzt aber raus!

Polski rzeczownik wyjaśniony jest w [SZYM] jako „odźwierny, portier w restauracji, klubie, wyrzucający z lokalu pijanych i awanturujących się gości”. Jednostka thumaczeniowa odnosi się na [Prag] do polskiego thumaczenia filmu w reżyserii R. Herringtona z P. Swayzem w roli głównej, którego oryginalny tytuł brzmi „Road House” (zob. R. Herrington 1989a). Polski leksem mógłby zostać przetłumaczony na język niemiecki jako Rausschmeißer, jednak tłumacz zdecydował się na rozwiązanie kreatywne wprowadzając do translatu wyrażenie Jetzt aber raus!, będące jednocześnie jedną $\mathrm{z}$ możliwych kwestii wypowiadanych przez wspomnianego wykidajłę. Zaproponowany ekwiwalent pełni rolę tytułu w zadaniu polegającym na wypędzeniu z pewnego lokalu kilku awanturujących się gości, co podkreśla jego adekwatność na poziomie strukturalnym wspomnianej gry, jednak neutralizuje na [Prag] występującą w tekście wyjściowym aluzję. Tytuł amerykańskiego filmu został bowiem zapożyczony do języka niemieckiego, czego skutkiem jest obecność angielskiej frazy nominalnej Road House w niemieckim polisystemie (zob. R. Herrington 1989b). We wspomnianej sytuacji tak skonstruowany easter egg jest niezwykle trudny do przetłumaczenia ze względu na zastosowanie dwóch odmiennych technik przekładu w tłumaczeniu amerykańskiego filmu: z jednej strony tłumaczenia kreatywnego w odniesieniu do polskiego polisystemu (Road House przetłumaczone jako Wykidajło), z drugiej zaś zapożyczenia w niemieckim polisystemie. Najkorzystniejszym rozwiązaniem na [Prag] byłoby zatem wprowadzenie do przekładu polskiej produkcji multimedialnej niemieckiego rzeczownika Rausschmeißer, który w kontekście wymienionej produkcji R. Herringtona odnosił się do granego przez P. Swayzego głównego bohatera i był używany przez bohaterów pobocznych w niemieckiej wersji filmu. Należy jednak zaznaczyć, że mimo wprowadzenia do przekładu wspomnianego leksemu opisywana aluzja nie będzie aż tak intensywna jak w tekście wyjściowym i może nie być odszyfrowana przez wszystkich użytkowników. pol. Teoria spisku - niem. Verschwörungstheorie

${ }^{15}$ [DUD]: „für besser, jünger, neuer, etw. anderes gehalten werden, als es der Wirklichkeit entspricht", thum.: E.L. 
Polska jednostka thumaczeniowa stanowi frazę nominalną złożoną z dwóch rzeczowników prostych. Leksem teoria [SZYM] przedstawia jako „ogólną koncepcję opartą na poznaniu i zrozumieniu istotnych czynników kształtujących pewną sferę rzeczywistości (np. w zakresie praw przyrody, procesów społecznych); konstrukcję myślową tworzącą z elementów pewną spoistą całość (np. w zakresie matematyki)", a rzeczownik spisek wyjaśnia jako ,tajne porozumienie grupy osób dla wspólnego osiągnięcia jakiegoś celu; sprzysiężenie, zmowa". Na poziomie [Prag] opisywana grupa imienna stanowi również odniesienie do polskiego przekładu tytułu amerykańskiego filmu z roku 1999 w reżyserii R. Donnera z M. Gibsonem w roli głównej (ang. Conspiracy Theory, zob. R. Donner 1999a). Wspomniany tytuł filmu został przetłumaczony na język niemiecki jako Fletchers Visionen (zob. R. Donner 1999b), gdzie rzeczownik Fletchers funkcjonuje jako nazwa własna - antroponim odnoszący się do nazwiska głównego bohatera filmu, a leksem Visionen wyjaśniony jest w

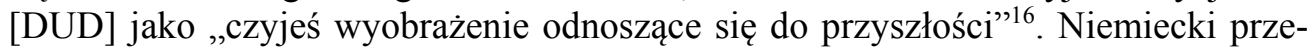
kład omawianego tytułu filmowego może być rozumiany jako wizje głównego bohatera dotyczące przedstawianych w filmie wydarzeń. Zaproponowany przez tłumacza gry komputerowej ekwiwalent Verschwörungstheorie jest jednocześnie próbą dosłownego tłumaczenia polskiej jednostki thumaczeniowej teoria spisku i prowadzi do zgodności tekstu wyjściowego i translatu na poziomie [REF]. Pełnej neutralizacji ulega natomiast poziom [Prag] przekładu, co prowadzi do niemożności odniesienia ekwiwalentu do niemieckiej wersji tytułu amerykańskiego filmu. W celu uzyskania większej wierności pragmatycznej korzystniejsze okazuje się wprowadzenie do przekładu grupy rzeczownikowej Detmolds Visionen, w której leksem Detmolds zastępuje występujący w niemieckim tytule antroponim Fletchers i odnosi się do zastosowanego $\mathrm{w}$ kontekście polskiej gry komputerowej antroponimu określającego imię jednego $\mathrm{z}$ bohaterów pobocznych, snującego tytułowe spiskowe wizje detronizacji panującego króla Henselta z Kaedwen. Rzeczownik Visionen stanowi natomiast językowe narzędzie do stworzenia skojarzeń z niemieckim przekładem tytułu amerykańskiego filmu, występując jednocześnie w niemieckiej wersji omawianej tu produkcji kinematograficznej i multimedialnej.

\subsection{Tłumaczenie easter eggów powstałych $\mathrm{w}$ wyniku przeróbki}

pol. Ostatni skok gangu Seliny - niem. Die letzten Untaten der Selina-Bande

Polska jednostka leksykalna jest grupą imienną złożoną z przymiotnika i trzech rzeczowników. Jej podstawę stanowi rzeczownik skok, który [SZYM] opisuje w nawiązaniu do danego kontekstu użycia jako „wypad rabunkowy; kradzież”. Przymiotnik ostatni występuje w ww. frazie nominalnej w znaczeniu ,znajdujący się na końcu; kończący jakiś cykl, szereg, jakąś serię itp.; taki, po którym nie będzie innego”, a leksem gang jako „zorganizowana grupa przestępców; banda, szajka bandytów" (zob. [SZYM]). Rzeczownik Selina jest w omawianym tu kontekście antropo-

${ }^{16}$ [DUD]: ,in jmds. Vorstellung bes. in Bezug auf Zukünftiges entworfenes Bild“, thum.: E.L. 
nimem i odnosi się na płaszczyźnie [REF] do żeńskiego imienia. Na płaszczyźnie [Prag] opisana jednostka tłumaczeniowa stanowi również odniesienie do thumaczenia tytułu popularnego wśród młodzieży komiksu „Wielki skok Seliny” (ang. „Selina's big score"), o czym może świadczyć użycie rzeczownika skok oraz nazwy własnej Selina, które obecne są także w przekładzie komiksu (zob. D. Cooke/ E. Brubaker 2002/2017). Twórcy gry komputerowej zmodyfikowali więc istniejący w polskim polisystemie i tym samym potencjalnie znany polskiemu odbiorcy tytuł „Wielki skok Seliny" poprzez zamianę przymiotnika wielki na ostatni, a także poprzez wprowadzenie niewystępującego w polskiej wersji komiksowego tytułu rzeczownika gang. Tłumacz gry komputerowej zdecydował się na zastosowanie w zastępstwie za polski leksem skok niemieckiego rzeczownika w liczbie mnogiej Untat, który [DUD] opisuje jako „zły, straszliwy, przestępczy, niegodziwy czyn” ${ }^{17}$, co stanowi wyraz generalizacji tekstu docelowego. Tłumacz zrezygnował także z rzeczownika Gang, który słownikowo definiowany jest jako „zorganizowana współpraca między przestępcami”" ${ }^{\prime 18}$, i wprowadził do translatu definiowany w [DUD] jako ,zorganizowana grupa przestępcza" ${ }^{19}$ rzeczownik Bande, co również jest oznaką generalizacji (rzeczownik Gang odnosi się bowiem, w przeciwieństwie do Bande, do grup przestępczych o większej liczebności i bardziej zorganizowanych - stąd też obecność leksemu Zusammenschluss w niemieckiej definicji, zob. przypis 17). Należy zaznaczyć, że omawiany tytuł komiksu został przetłumaczony na język niemiecki jako „Selinas großer Coup” (zob. D. Cooke/ E. Brubaker 2015). [DUD] opisuje rzeczownik Coup jako „na chłodno zaplanowane, udane przedsięwzięcie”20. Propozycja tłumacza jest zatem próbą dosłownego tłumaczenia polskiego przekładu tytułu amerykańskiego komiksu na język niemiecki, co skutkuje całkowitą neutralizacją ekwiwalentu na [Prag]. Aby uzyskać większą wierność na [Prag], należałoby stworzyć odbiorcy tekstu docelowego stosowny punkt odniesienia na płaszczyźnie językowej. Można to zrobić poprzez zastosowanie jednostek leksykalnych użytych w niemieckim przekładzie amerykańskiego komiksu, np. letzter Coup von Selinas Gang.

\section{pol. Sekretne życie hrabiego Romilly - niem. Das geheime Leben des Grafen Romilly}

Polska jednostka tłumaczeniowa jest frazą nominalną, której podstawę stanowi rzeczownik życie, wyjaśniony w [SZYM] m.in. jako „objawy istnienia gdzieś wielu istot żywych, przebywania gdzieś ludzi, ruch”, do którego dodano występujący w formie przydawki przymiotnik sekretny oraz leksem hrabia. Wymieniony przymiotnik zdefiniowany jest w [SZYM] jako „nie przeznaczony do wiadomości ogółu, trzymany w sekrecie, poufny, tajny", natomiast rzeczownik hrabia odnosi się do antroponimu Romilly i opisany jest w [SZYM] jako ,tytuł arystokratyczny; osoba nosząca ten tytuł". Na [Prag] opisywana jednostka thumaczeniowa nawiązuje do

\footnotetext{
${ }^{17}$ [DUD]: ,böse, grausame, verbrecherische, verwerfliche Tat", thum.: E.L.

18 [DUD]: ,„organisierter] Zusammenschluss von Verbrechern“, thum.: E.L.

19 [DUD]: „organisierte Gruppe von Verbrechern“, thum.: E.L..

20 [DUD]: „,ühn angelegtes, erfolgreiches Unternehmen“, tłum.: E.L..
} 
polskiego tłumaczenia tytułu filmu produkcji amerykańskiej w reżyserii B. Stillera „Sekretne życie Waltera Mitty” (zob. B. Stiller 2013a). Twórcy polskiej gry komputerowej tworząc opisywaną tu aluzję dokonali zamiany występującego $\mathrm{w}$ polskim thumaczeniu antroponimu Walter Mitty na frazę nominalną hrabia Romilly, której częścią składową jest również antroponim. Wspomniany film został przetłumaczony na język niemiecki jako „Das erstaunliche Leben von Walter Mitty” (zob. B. Stiller 2013b), co skłania do wniosku, że zaproponowany przez tłumacza gry komputerowej ekwiwalent stanowi próbę dosłownego przekładu polskiego tłumaczenia tytułu wymienionego powyżej filmu amerykańskiego. Skutkuje to neutralizacją na [Prag] tekstu docelowego. W celu uzyskania większej wierności pragmatycznej wystarczyłoby zdefiniować występującą w niemieckiej wersji tytułu frazę nominalną Das erstaunliche Leben von jako podstawę ekwiwalentu przekładowego, pozostawiając ją tym samym w języku docelowym bez zmian, aby stanowiła ona stosowny punkt odniesienia do tytułu używanego w obrębie niemieckiego polisystemu. Kolejnym krokiem byłoby wówczas dosłowne przetłumaczenie frazy nominalnej w dopełniaczu hrabiego Romilly jako des Grafen Romilly. Utworzony w ten sposób odpowiednik das erstaunliche Leben des Grafen Romilly gwarantuje wierność na płaszczyźnie [Prag] translatu.

\section{Wnioski}

W niniejszym artykule opisano sposób tworzenia i thumaczenia easter eggów, czyli występujących w produkcjach multimedialnych aluzji o funkcji ludycznej. W centrum zainteresowania znalazły się easter eggi powstałe w wyniku procesu zapożyczeń, przekładu oraz przeróbki. W każdej z wymienionych grup opisano ze względów ekonomicznych po dwa przykłady pochodzące ze stworzonych przez polską firmę CD-Projekt RED gier komputerowych „Wiedźmin”, „Wiedźmin 2: Zabójcy Królów” oraz „Wiedźmin 3: Dziki Gon” wraz ze wszystkimi opublikowanymi rozszerzeniami. Zgromadzone w trzech grupach przykłady zostały przetłumaczone w sposób dosłowny (por. Sekretne życie hrabiego Romilly, Ostatni skok gangu Seliny oraz Teoria spisku) oraz kreatywny (por. Dziady, Nasza szkapa, Wikidajło), jednak zastosowane przez tłumacza techniki doprowadziły do neutralizacji na poziomie [Prag] tekstu docelowego, co w przypadku aluzji spowodowało, iż nie są one rozpoznawalne w tekście przekładu. Zaproponowane przez nas ekwiwalenty funkcjonalne wynikają ze ściśle określonych technik przekładu, które różnią się od siebie w zależności od zaklasyfikowania danego easter eggu do jednej z wyżej wymienionych grup. I tak, easter eggi powstałe $w$ wyniku zapożyczenia powinny odwoływać się do funkcjonujących już w polisystemie języka docelowego tekstów. Techniką tłumaczenia gwarantującą sukces byłoby więc zapożyczenie jednostki leksykalnej, do której w sposób dosłowny dana aluzja nawiązuje (np. dla easter eggu Dziady trafnym ekwiwalentem byłby leksem Totenfeier, ponieważ został on zastosowany jako tytuł w niemieckim przekładzie dramatu Mickiewicza). Easter eggi powstałe w wyniku procesu przekładu odwołują się do funkcjonujących w polisystemie języka wyjściowego tytułów tłumaczonych utworów. Odniesienie sukcesu w transferze tego typu aluzji do języka docelowego wymaga od tłumacza dokładnej znajomości 
polisystemu języka docelowego oraz wytworzonych w nim interrelacji. Stosowną techniką przekładu jest zatem $\mathrm{w}$ tym przypadku przeniesienie do tekstu docelowego jednostek leksykalnych będących tłumaczeniami tytułów innych utworów, aby utworzyć w świadomości odbiorcy tekstu docelowego stosowne punkty odniesienia (np. w celu adekwatnego przetłumaczenia frazy nominalnej teoria spisku należy odwołać się do niemieckiego przekładu wspomnianego filmu, tzn. „Fletchers Visionen"). W przypadku trzeciej grupy, a więc easter eggów powstałych w wyniku procesu przeróbki, niezwykle istotna $\mathrm{z}$ translatorycznego punktu widzenia jest znajomość konkretnych schematów tworzenia tego typu aluzji, które mogą się od siebie różnić. Szczególnie ważna okazuje się tu więc nie tylko znajomość relacji polisystemowych w obrębie języka wyjściowego i docelowego, ale przede wszystkim gruntowna lingwistyczna analiza tekstu wyjściowego, a także ustalenie inwariantywności oraz wariantywności jednostek tłumaczeniowych. Należy przy tym założyć, że inwariant ma stanowić podstawę do odszyfrowania danej aluzji przez odbiorcę tekstu przekładu (a więc jest swego rodzaju elementem stałym, występującym w formie wyjściowej oraz przeróbce), a wariantywność polega na określeniu tego, które z form językowych można zamienić na inne (np. w próbie przekładu aluzji sekretne życie hrabiego Romilly tłumacz musi odwołać się do niemieckiego przekładu filmu „The Secret Life of Walter Mitty” dokonując wymiany antroponimu Walter Mitty na dosłowne tłumaczenie frazy nominalnej w dopełniaczu hrabiego Romilly na wzór zastosowanego w tekście wyjściowym schematu tworzenia).

\section{Bibliografia}

Barańczak, S. (2004), Ocalone w thumaczeniu, Kraków.

CD-PROJEKT RED (2007), Wiedźmin. Polska.

CD-PROJEKT RED (2011), Wiedźmin 2: Zabójcy Królów. Polska.

CD-PROJEKT RED (2015), Wiedźmin 3: Dziki Gon. Polska.

CD-PROJEKT RED (2015), Wiedźmin 3: Serca z Kamienia. Polska.

CD-PROJEKT RED (2016), Wiedźmin 3: Krew $i$ wino. Polska.

Cherkas, N. V. (2004), Linguostylistic Means of Conveying Biblical Motifs in the Postwar American Novel. L'viv.

Cooke, D./ Brubaker, E. (2015), Selinas großer Coup. Hamburg.

Cooke, D./ Brubaker, E. (2002/2017), Wielki skok Seliny. Warszawa.

Dąbrowski, M. (2000), Postmodernizm: Myśl i tekst. Kraków.

Delahunty, A./ S. Dingen/ P. Stock (2001), The Oxford Dictionary of Allusions. New York. [AL].

Deutsches Universalwörterbuch DUDEN (2007), Mannheim-Leipzig-Wien-Zürich. [DUD].

Donner, R. (1999a), Teoria spisku, (w:) Portal Filmweb.pl. (URL http://www.filmweb.pl/Teoria.Spisku). [Pobrano: 12.05.2017].

Donner, R. (1999b), Fletchers Visionen, (w:) Portal Moviepilot.de (URL http://www.moviepilot.de/movies/fletchers-visionen). [Pobrano: 12.05.2017]. 
Easter Egg (2016), (w:) Wikipedia: Wolna Encyklopedia. (URL https://pl.wikipedia.org/wiki/Easter_egg [Pobrano: 12.05.2017].

Even-Zohar, I. (1990), Polysystem Studies, (w:) „Poetics today 11/1”.Tel-Aviv, 1268.

Heidemann, G. (2017), Convivium 8. Łódź (w druku).

Heinemann, W. (1997), Zur Eingrenzung des Intertextualitätsbegriffes aus textlinguistischer Sicht, (w:) J. Klein/ U. Fix (red.), Textbeziehungen: linguistische und literaturwissenschaftliche Beiträge zur Intertextualität. Tübingen, 21-37.

Hendryk, E. (2001), Auf dem Weg zu einem kreativen Umgang mit dem Internet, (w:) E. Hendryk/ J. Watrak (red.), Internet als neue kreative Ausdrucksform. Koszalin, 9-19.

Herrington, R. (1989a), Wykidajto (w:) Portal Filmweb.pl. (URL http://www.filmweb.pl/film/Wykidaj\%C5\%82o-1989-11815\#). [Pobrano: 12.05.2017].

Herrington, R. (1989b), Road House, (w:) Portal Moviepilot.de. (URL http://www.moviepilot.de/movies/road-house). [Pobrano: 12.05.2017].

Kalinowski, L. (1981), O możliwościach odczytywania dzieła sztuki, (w:) J. Białostocki et al. (red.), Tesera: sztuka jako przedmiot badań. Kraków, 106-120.

Kiklewicz, A. (2006), Język, komunikacja, wiedza. Mińsk.

Koller, W. (1992), Einführung in die Übersetzungswissenschaft. HeidelbergWiesbaden.

Konopnicka, M. (1890/2008), Nasza szkapa. Kraków.

Kuhnke, I. (1995), Polnische schöne Literatur in deutscher Übersetzung. Mainz.

Lebiedziński, H. (1989), Przekładoznawstwo ogólne wobec teorii enroi. Warszawa.

Lennon, P. (2001), Die Rolle von Anspielungen in britischen Zeitungstexten, (w:) „Zeitschrift für Angewandte Linguistik 34“, 5-25.

Lipiński, K. (2004), Vademecum tłumacza. Kraków.

Mickiewicz, A. (1832/2009), Dziady. Poznań.

Nida, E. (1969), Science of Translation, (w:) „Language” 45, 483-498.

Nycz, R. (2000), Tekstowy świat. Poststrukturalizm a wiedza o literaturze. Kraków.

Porazińska, J. (1925), Na Wojtusia z popielnika, (w:) „Dzidziusiowo” (URL http://dzidziusiowo.pl/file/na-wojtusia-janina-porazinska). 12.05.2017].

Schreiber, M. (1993), Übersetzung und Bearbeitung: Zur Differenzierung und Abgrenzung des Übersetzungsbegriffs. Tübingen.

Schultze, B. (1992), Montage in Tadeusz Różewicz Kartoteka und in den deutschen Übersetzungen: Poetische und andere Fremdheit als Aufgabe für Übersetzer, (w:) F. Lönker (red.), Die literarische Übersetzung als Medium der Fremdsprachenerfahrung. Berlin, 175-203.

Scorsese, M. (2002), Gangi Nowego Jorku, (w:) Portal Filmweb.pl. (URL http://www.filmweb.pl/Gangi.Nowego.Jorku). [Pobrano: 12.05.2017].

Stiller, B. (2013a), Sekretne życie Waltera Mitty, (w:) Portal Filmweb.pl. (URL http://www.filmweb.pl/film/Sekretne+\%C5\%BCycie+Waltera+Mitty-2013-

107587). [Pobrano: 12.05.2017]. 
Stiller, B. (2013b), Das erstaunliche Leben des Walter Mitty, (w:) Portal Moviepilot.de. (URL http://www.moviepilot.de/movies/das-erstaunliche-leben-deswalter-mitty). [Pobrano: 12.05.2017].

Stolze, R. (2005): Übersetzungstheorien. Eine Einführung. Tübingen.

Sulikowski, P. (2013), Mountains and Words - Tadeusz Różewicz's Selected Poems in English. On Translation Techniques in the Language of Poetry. Hamburg.

Sulikowski, P. (2016), Der literarische Text und I-Faktoren in der Übersetzung. Anhand ausgewählter Werke Zbigniew Herberts im Deutschen und Englischen. Frankfurt am Main

Szymczak, M. (1981), Stownik języka polskiego. Warszawa. [SZYM]

Świerkocki, M. (1997), Postmodernizm: Paradygmat nowej kultury. Łódź.

Święch, J. (1984), Przekłady i autokomentarze (w:) E. Balcerzan (red.), Wielojęzyczność literatury a problemy przekładu artystycznego. Wrocław-WarszawaKraków-Gdańsk-Łódź, 44-66.

Urbanek, D. (2004), Pęknięte lustro: Tendencje $w$ teorii i praktyce przekładu na tle myśli humanistycznej. Warszawa. 